\title{
Pre-Service Teachers Performance in Designing Mathematics Learning Devices Using Problem Based Learning Model
}

\author{
Masriyah Masriyah ${ }^{1^{*}}$ and Umi Hanifah ${ }^{1,2}$ \\ ${ }^{1}$ Universitas Negeri Surabaya, Mathematics Department, Surabaya, Indonesia \\ ${ }^{2}$ Institut Teknologi dan Sains Nahdlatul Ulama Pasuruan, Mathematics Department, Pasuruan, Indonesia
}

\begin{abstract}
A descriptive research which is purpose to describe pre-service teachers' ability in designing a mathematics learning devices using problem-based learning models were done. The subjects of this research were pre-service teachers who programmed Innovative Learning course consisting of 32 people. Data collection was carried out using the assignment method, while data analysis was carried out by paying attention to whether or not students were able to (1) formulate indicators based on basic competencies, (2) formulate learning objectives based on learning indicators, (3) design subject matter in accordance with learning objectives, (4) choose learning materials that are in accordance with the learning model or method, (5) design learning activities according to learning objectives, (6) design "constructivist" worksheet (7) design assessment instruments according to learning indicators, (9) alternative answers according to the questions asked. prepared, (10) The scoring guidelines are in accordance with the prepared test questions. Based on the results of data analysis, it can be stated that pre-service teachers are competent in designing learning devices using problem-based learning models. In addition, their mathematics learning devices using problem-based learning model have met good criteria.
\end{abstract}

Keywords: pre-service teachers, mathematics learning devices, descriptive reserach

\section{Introduction}

Education is a process that involves several interrelated elements, namely teachers, students, curriculum and infrastructure. The elements of education are expected to be able to create quality education through the learning process. Learning is a process of interaction between students and educators and learning resources in a learning environment. A good learning process can only be created through good and appropriate planning. The success of an effort is determined by various factors. The teacher is one element of education that plays an important role in directing students to succeed in the learning process activities.

The preparation of good learning devices will have a good impact as well. These learning devices become guideline for a teacher to be able to direct students to learn well. A good teacher will always make plans for his learning activities, so there is no reason for a teacher to teach in class without learning devices. The teacher is the person who is directly responsible for realizing what is contained in the learning device. This is because the teacher directly implements the learning devices in the classroom. Thus, the learning devices depend a lot on the teacher's ability to develop it. With good lesson planning, teachers will be steady in front, and can increase teaching and learning interactions between teachers and students. For this reason, teachers must design learning activities, such as formulating indicators and learning objectives, selecting learning materials, choosing learning methods or models, designing learning activities, and establishing assessment instruments.

Teachers are human resources who become planners, actors and determinants of achieving educational goals. Teachers are required to make effective and efficient plans. Professional teachers are required to always be serious in planning good lessons that are suitable for their students. "Teacher competencies as referred to in Article 8 include pedagogic competence, personality competence, social competence, and professional competence obtained through education. profession" [1]. The pedagogic competence in question is the ability to understand students, design and implement learning, evaluate learning outcomes, and develop students to actualize their various potentials.

Mathematics Education of Universitas Negeri Surabaya is one of the institutions that prepares educators who will enter the community as teachers. Mathematics Education students, during the learning process are provided with Innovative Learning courses. In these courses, pre-service teachers are provided with several materials about learning models and their

\footnotetext{
* Corresponding author : masriyah@unesa.ac.id
} 
implementation, how to design learning devices with certain learning models then practiced in groups and individually. In designing good learning devices, it is necessary to be able to formulate learning indicators from a basic competency, formulate learning objectives from learning indicators, design learning materials that are in accordance with learning objectives, choose learning materials that are in accordance with learning model, and develop assessment instruments that are in accordance with indicators. learning.

Pre-service students of mathematics education are still lacking in preparing learning scenarios with a scientific approach [2]. Meanwhile, based on the experience of researchers guiding Mathematics Education students in simulations to prepare for teaching practice, it turns out that there are still many students who have difficulties in designing good quality learning. Some students design learning that there is no match between learning objectives and learning activities as well as learning methods or models. Several other students, designing assessment instruments that are not in accordance with learning indicators, and many still have difficulty in designing constructivist worksheets for the learning process that can activate students in learning activities.

"Teacher competencies include: pedagogic competence, personality competence, social competence and professional competence obtained through professional education" [1]. Pedagogic competence is a person's ability to manage student learning which includes understanding students, designing and implementing learning, evaluating learning outcomes, and developing students to actualize the potential of students.

The teaching and learning process applied by the teacher should be based on the results of a serious study, not just because of the textbook, the method, or our convenience in carrying it out [3]. Mathematics teachers must design lessons that provide the greatest opportunity for achieving the formulated goals. Learning design allows ensuring learning that is in line with the goals to be achieved, and therefore, students will display what the learning really wants [4].

It is further said that with a good learning design, in addition to what and how students should learn something, how students behave is also designed. The character of students are also formed from good learning design. Therefore, learning design is an important thing that should not be overlooked.

Education experts have agreed that learning design is important and vital for the professionalism of a teacher [5]. This design is the key in determining how the interaction process of students with learning resources will take place, and how great the learning outcomes will be. Therefore, the development of learning designs should not be done arbitrarily. Merely imitating learning plans that have been made by others is not the right thing.

Changing the curriculum from KTSP to Curriculum 2013, which demands a change in learning models also increasingly requires teachers to have the ability to design better learning [6]. The practice of "copy and paste" which has been suspected to have occurred among students as teachers, or prospective teachers, one of which is caused by their inability to formulate lesson plans, should be kept to a minimum or stopped as much as possible. They should be helped to develop good learning devices.

In planning learning, the teacher must determine a scenario or strategy or commonly called learning steps well so as to create a pleasant learning atmosphere for students. In order for the implementation of the learning process to run effectively and efficiently, a systematic planning is needed. In order for students to be active in learning, a more meaningful teaching and learning process is needed and designed in a clear scenario.

Professional teachers are required to be able to build a good learning process so that it can produce quality educational outputs and outcomes. To produce quality educational outputs and outcomes, a teacher must design their learning well. Planning is a projection (estimate) of what is needed in order to achieve valid and valuable goals [7]. Broadly speaking, teaching planning includes activities to formulate what goals will be achieved by a teaching activity, in what ways. used to assess these objectives, what materials will be delivered, how to deliver them, and what tools or media are needed [8]. So, learning devices are plans made by the teacher to project what activities will be carried out by the teacher and students so that the goals can be achieved.

Components of learning planning include: (1) learning objectives, (2) content (learning materials), (3) learning activities, (4) media and learning resources; and (5) evaluation [9]. Meanwhile, the learning component consists of learning objectives, subject matter, teaching and learning activities, methods, media, learning resources, and evaluation [10]. What distinguishes between the components proposed by the two is the presence or absence of learning methods in the components of learning planning.

Based on the background of the research, the researchers are interested in conducting a study with the title "Pre-service Teachers Performance in Designing Mathematics Learning Devices Using Problem Based Learning Model". The purpose of this study is to describe: (a) the ability of Mathematics Education students in designing Mathematics learning devices, (b) the quality of the results of Mathematics learning designs made by students who program Innovative Learning courses.

\section{Method}

This type of research includes descriptive research. What is described in this study is the ability of students to design learning devices in the Innovative Learning course and the quality of the learning devices made.

This research was carried out in Mathematics Education study program of the Unesa, with the research subjects being all students who programmed the Innovative Learning course consisting of 32 people.

The steps that the researchers took in this study can be presented in the form of a diagram as follows. 


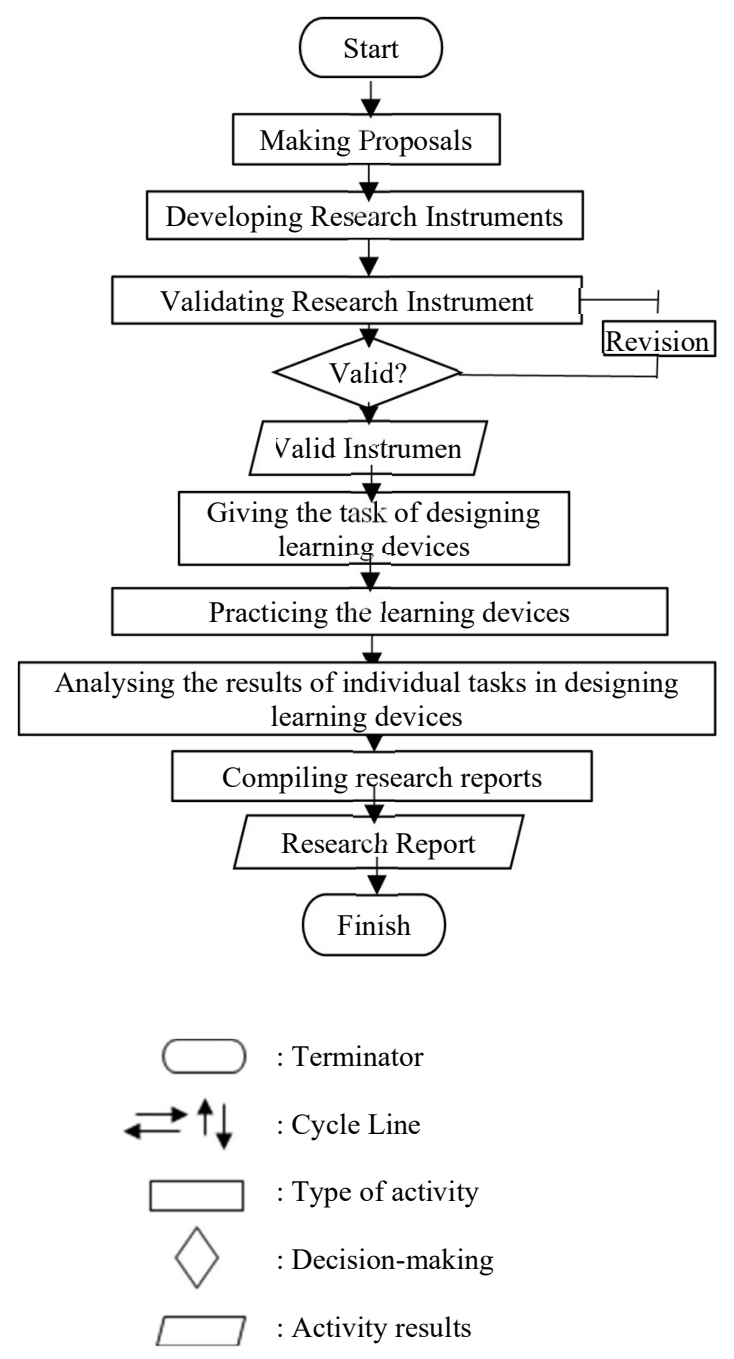

Fig. 1. Diagram of the steps that the researchers took.

The data obtained in this study were then analyzed and directed to answer research questions. The activities carried out in data analysis activities are making corrections to the results of the learning design task, taking into account: (1) The suitability of learning indicators with basic competencies, (2) Conformity of learning objectives with learning indicators, (3) Suitability of learning materials with learning objectives, (4) The suitability of the learning model/method with the learning objectives, (5) The suitability of the learning model/method with the learning materials, (6) The suitability of the learning activities with the learning objectives, (7) The quality of the designed "constructivist" worksheet, (8) The suitability of the instrument assessment with learning indicators, (9) The suitability of alternative answers to the prepared test questions, (10) The suitability of the scoring guidelines with the assessment instrument.

The next step is to conduct an analysis using qualitative descriptive analysis, with the following steps: (1) Analyzing whether or not the learning devices prepared by each student are based on each specified criteria, (2) Calculating the frequency and percentage of conformity and incompatibility of each student's lesson plans with the model. learning based on problems, (3) grouping each student into competent or incompetent Pre-service Teachers, (4) calculating the percentage of Pre-service Teachers who are competent in designing mathematics learning devices, (5) grouping the abilities of mathematics education Pre-service Teachers in designing mathematics learning devices can be categorized as follows.

Table 1. Category of Pre-service Teachers Performance

\begin{tabular}{|c|c|}
\hline Interval & Category \\
\hline $\mathrm{P}>85 \%$ & Very competent \\
\hline $70 \%<\mathrm{P}<85 \%$ & competent \\
\hline $55 \%<\mathrm{P}<70 \%$ & Competent enough \\
\hline $40 \%<\mathrm{P}<55 \%$ & Less competent \\
\hline $\mathrm{P}<40 \%$ & Incompetent \\
\hline
\end{tabular}

Then, the quality of Mathematics' learning devices prepared by students, is determined by the following criteria.

Table 2. Category of Learning Devices

\begin{tabular}{|c|c|}
\hline Interval & Category \\
\hline $\mathrm{P}>85 \%$ & Very good \\
\hline $70 \%<\mathrm{P}<85 \%$ & good \\
\hline $55 \%<\mathrm{P}<70 \%$ & Good enough \\
\hline $40 \%<\mathrm{P}<55 \%$ & Less good \\
\hline $\mathrm{P}<40 \%$ & $\mathrm{Bad}$ \\
\hline
\end{tabular}

\section{Research Results and Discussion}

The results of the task of Designing Mathematics Learning Devices using problem-based learning models can be stated as follows:

1. A total of 25 students $(78.13 \%)$ were able to formulate indicators in accordance with basic competencies,

2. A total of $23(71.88 \%)$ students were able to formulate learning objectives based on learning indicators,

3. A total of 25 students $(78.13 \%)$ were able to design subject matter according to the learning objectives,

4. A total of 20 students $(62.50 \%)$ were able to choose the learning model $/$ method that was in accordance with the learning objectives,

5. A total of 23 people (71.88\%) students were able to choose a model/learning method that was in accordance with the learning material, 
6. A total of 30 students $(93.75 \%)$ were able to design learning activities according to learning objectives,

7. A total of 17 students $(84.38 \%)$ were able to design a "constructivist" LKPD,

8. A total of 20 students $(62.50 \%)$ were able to design assessment instruments according to learning indicators,

9. A total of 28 people $(81.25 \%)$ students were able to alternative answers according to the prepared test questions,

10. A total of 28 people $(75.00 \%)$ students were able to score guidelines according to the prepared test questions,

Overall, the average percentage of Mathematics learning device components compiled by Mathematics Education undergraduate students who have met good criteria for problem-based learning models is $76.5625 \%$, while the average percentage of Mathematics Education undergraduate students' abilities in designing Mathematics learning by learning model based on the problem of $81.25 \%$.

\section{Conclusions}

Based on the results of the data analysis of the research that has been done, it can be concluded that undergraduate students of Mathematics education are "competent" in designing Mathematics learning devices, because the average percentage of students' abilities in designing learning devices is more than $70 \%$.

In addition, mathematics learning devices compiled by mathematics education Pre-sevice Teachers have met good criteria because the percentage of learning device components that have met good criteria. Although the almost all of Pre-sevice Teachers are competent in designing mathematics learning decices, there are components of the equipment that need to get the attention of innovative learning lecturers because the percentage of Pre-service teachers performances still less than $70 \%$, namely the component choosing learning models/methods that are in accordance with learning objectives, and components of designing assessment instruments according to learning indicators

\section{References}

[1] Undang-Undang Nomor 14 Tahun 2005 tentang Guru dan Dosen, pada pasal 10 ayat (1) dan Pasal 8

[2] Nursalam, Muhammad Rusydi Rasyid. 2016. Studi Kemampuan Mahasiswa Mendesain Perencanaan Pembelajaran Matematika Di Sekolah Menengah Pertama Berbasis Pendekatan Saintifik. Makassar. Jurnal Matematika dan Pembelajaran. Fakultas Tarbiyah dan Keguruan UIN Alauddin

[3] Wiggins, G. and McTighe, 2009. Understanding by Design: Extended 2nd Edition. Alexandria, VA: ASCD.

[4] Duncan, G. and Met, M. M. 2010. Startalk: From Paper to Pencil. College Park. MD: National Foreign Language Center at the Univers ity of Maryland.
Available

www.startalk.umd.edu/lesson planning.

[5] Mahmud, N. 2010. Learning to Plan: An Investigation of Malaysian Student Teacher's Lesson Planning During Their Practicum. A Thesis to be Submitted to University of East Anglia for the degree of Doctor of Philosophy. University of East Anglia.

[6] As'ari, A.R. 2014. Berbagai Permasalahan Pembelajaran Matematika dalam Kurikulum 2013, dan Beberapa Upaya untuk Mengatasinya: Makalah disajikan dalam Seminar Nasional 'Solusi Problematika Implementasi Kurikulum 2013 untuk Mewujudkan Pembelajaran yang Berkualitas.Jember: Himpunan Mahasiswa Matematika FKIP Universitas Jember, 16 Maret 2014

[7] Kaufman, R. A., 1972. Educational System Planning. NJ: Prentice-Hall

[8] Ibrahim, R., Sukmadinata, N. S. 2010. Perencanaan pengajaran. Jakarta: Rineka Cipta

[9] Masitoh, dkk. 2005. Strategi Pembelajaran. Jakarta: Universitas Terbuka.

[10] Sutikno, S. 2009. Belajar dan Pembelajaran. Bandung: Prospect. 